\title{
Systematic neglect of men as a key population in tuberculosis
}

Katherine C. Horton ${ }^{\mathrm{a}, \mathrm{b}^{*}}$, Richard G. White ${ }^{\mathrm{b}, \mathrm{c}}$, Rein M. G. J. Houben ${ }^{\mathrm{b}, \mathrm{c}}$

a Department of Clinical Research, London School of Hygiene and Tropical Medicine, London, United Kingdom, Keppel Street, London WC1E 7HT, United Kingdom

b Tuberculosis Modelling Group, Tuberculosis Centre, London School of Hygiene and Tropical Medicine, London, United Kingdom, Keppel Street, London WC1E 7HT, United Kingdom

${ }^{c}$ Department of Infectious Disease Epidemiology, London School of Hygiene and Tropical Medicine, London, United Kingdom, Keppel Street, London WC1E 7HT, United Kingdom

* Keppel Street, London WC1E 7HT, United Kingdom, katherinehorton12@gmail.com

\section{Keywords}

Tuberculosis, gender, men, women, policy

\section{Conflicts of interest}

Authors have no conflicts of interest and no financial interests.

\section{Running head}

Systematic neglect of men in TB

(C) 2018. This manuscript version is made available under the CC-BY-NC-ND 4.0 license http://creativecommons.org/licenses/by-nc-nd/4.0/ 
Leaders in the global tuberculosis $(\mathrm{TB})$ response tell us that the disease has "particularly severe consequences for women" [1], that "they [women] are drastically and disproportionately affected" [2 p. 1], and that "it is essential [to consider] the needs of key affected women and girls" [3 p. 8]. When discussing gender and TB, other international and regional policy, funding, and advocacy groups share this near exclusive focus on the needs of women and girls. However this emphasis runs counter to a wealth of evidence, with decades of data consistently indicating that men have a higher burden of TB disease, are diagnosed later, and have worse outcomes than women.

Global and regional TB incidence, case notifications, and deaths have been higher for men than women every year that estimates have been reported [4]. While the male excess in these estimates has often been assumed to reflect a female disadvantage in accessing care, prevalence surveys considered the most accurate measure of disease burden [5] - confirm increased male vulnerability with even greater gender disparity in the underlying burden of undiagnosed or untreated disease at the community level $[5,6]$. Our systematic review of 56 surveys in 24 countries found that men are 2.2 times as likely as women to have prevalent disease, and over $70 \%$ of prevalent infectious (smear-positive) cases are among men [6]. Our review also found that men are significantly less likely than women to have their disease diagnosed and reported [6], as previously indicated by a meta-analysis of 29 surveys in 14 countries [7]. More recently, our modelling work found that delays from disease onset to treatment initiation are a year longer for men than women in Viet Nam and Malawi [8]; data suggest similar disparities in timely access to treatment exist elsewhere. As such, even methods that are known to underestimate men's relative burden of disease [9] suggest that two-thirds of the "missing" millions of adults with TB are men $[4,10]$. Men who do access diagnostic services often are less likely to complete treatment and have worse outcomes than women, according to a systematic review of 62 studies in 48 countries [11]. Rates of disease recurrence are higher among men than women $[12,13]$, and ultimately almost twice as many men as women are reported to die from TB each year [5]. 
This overwhelming evidence should be enough, first, to drive policy and resources appropriately towards men, and, second, to mandate efforts to successfully reach men with TB services. Yet, as of September this year, such aims are absent from the limited gender-specific language from major global policy and funding bodies. While many organisations have begun to acknowledge the relative burden of disease in men $[1$ p. 5,3 p. 52, 5 p. 29,14 p. 1,15 p. 5,16 p. 4,17 p. 9,18 p. 4 , 19 p. 1, 20, 21 p. 55], only the Global TB Report mentions the need to improve men's access to and utilisation of health services [5]. The same organisations, including, but unfortunately not limited to, the World Health Organization [1 p. 2, 16], the StopTB Partnership [20 p. 53, 21 pp. 2,5], the Global Fund to Fight AIDS, Tuberculosis and Malaria [2 p. 4, 18 pp. 1-4, 22 p. 3] and the United Nations Development Programme [15 pp. 6,16, 19 p. 11] instead continue to focus their genderspecific recommendations on women (Table 1). This focus reflects a deeper problem of gender blindness resulting from decades of relative indifference to men's health across policy, funding, research, programmatic, advocacy, and civil society communities.

What lies behind the systematic neglect of men in TB? Almost certainly, a key driver is the strong focus placed on gender equality under the Millennium and Sustainable Development Goals [23, 24]. The goals rightly focus on the empowerment of women and girls to overcome the profound consequences of current and historic economic and power disadvantages suffered by women. These inequities must be addressed. However, a traditional approach to gender equity focused solely on women's vulnerabilities should not be blindly applied to TB care and prevention efforts. While women, and specifically pregnant women [25], face specific barriers [26] that deserve attention, these should not define the gendered response to TB.

The data showing men's excess burden of disease and disadvantage in care have been misinterpreted or ignored for too long. Gendered discussions of TB focus too often on the very few isolated settings in which more new cases are regularly notified among women, particularly Afghanistan and Iran [16 p. 9, 19 p. 4, 27 p. 2], which together account for less than one percent of annual TB notifications [4]. There is a general failure to recognise these settings as exceptions to 
global and regional trends and to acknowledge that these data are likely biased by men's widelyobserved disadvantage in accessing care [5,6]. Men's barriers to care are often overshadowed by a focus on the stigma that women face [18 p. 22,27 p. 5, 28 p. 8], without acknowledgement that "the psychological and social consequences [of TB] are harsh for both genders" [26] and stigma measurement tools may frequently underestimate stigma in men [29]. Furthermore, decades of data from countries with high HIV prevalence are frequently ignored, leading to an incorrect perception that more cases are notified among women in these settings [17 p. 5, 19 p. 9, 27 p. 5], when in fact case notification rates among men have exceeded those among women in $97 \%$ of annual countrylevel estimates since 1996 [4, 30]. Similarly, assertions that extra-pulmonary TB is more frequently diagnosed among women [21 p. 2] are not supported by data from the past decade, during which $10 \%$ more extra-pulmonary TB cases have been notified among men than women $[4,31]$. And while TB is regularly highlighted as a leading cause of death in women $[2$ p. 5, 3, 14 p. 29, 16 p. 1 , 19 p. 1,21 p. 8,27 p. 4, 32 p. 1], mortality data showing that the disease is the eighth leading cause of death in men [33] are rarely acknowledged.

The tendency to equate "gender" with "women" extends to academic literature, where a female bias dominates gender research [34], further driving the neglect of men. In its extreme, this tendency has manifested itself in systematic reviews that purport to describe gender differences in TB while restricting searches for relevant publications with terms that describe only women $[35,36]$. Other academic literature has at times misinterpreted data to highlight a supposed "feminisation" of the TB epidemic [37] that simply does not exist. Such studies contribute bias by providing one-sided “evidence" for global policy and funding bodies. Strong evidence showing men's excess burden and vulnerability in TB is then replaced with assumptions that settings with gender disparity must instead disadvantage women [20] and that the disease has a disproportionate effect on women [2, 38].

Now is the time to stop this long-standing systematic neglect of men. The TB community is undertaking a renewed drive towards ending TB [20], which has put fresh focus on key affected 
populations as a central component of the End TB Strategy [20, 39, 40]. Key affected populations have been defined to include "people at increased risk of TB because of biological or behavioural factors", including those undernourished (population attributable fraction, PAF, 27\%), those who use tobacco (PAF 23\%), those living with HIV (PAF 19\%), and those with diabetes (PAF 6\%), among others [20, 41] Men also clearly meet this criterion, with a PAF of $31 \%[6,42,43]$. Key affected populations also include "people who have limited access to quality TB services", specifically women in "settings with gender disparity" [20]. Again, evidence consistently shows that actually men are significantly less likely to access care [5-7] and do so later than women [8]. It is clear therefore that men meet not one, but two, out of three definitions for key affected populations.

Addressing gender disparities and inequalities in TB requires a shift towards an evidence-based approach to gender. Although overcoming deeply-engrained bias is a complex and difficult process, there is overwhelming evidence to support a shift in focus towards men, and the need to do so is urgent. Addressing men's burden of TB is imperative to improve men's health, but also to prevent disease in women, boys, and girls [44]. To make a start, we provide three key steps that must be taken.

The first step is for global policy and funding agencies to acknowledge the problem, given their influence on TB response at a global and country level. We suggest a rephrasing and redirection of policies and recommendations, as outlined in the third column of Table 1, recognising the evidence of men's excess burden of TB [6] and relative disadvantage in accessing and completing treatment $[7,10,11]$. To ensure evidence-based policies and programmatic guidance, researchers must work closely with policy and funding agencies, and those agencies must also be willing to listen to and act upon researchers' recommendations. Without this change in high-level recognition and guidance, it is unlikely that resources, research and programmatic action will follow. 
Acknowledgement should be followed by research funding across a range of fields to address the knowledge gaps around men's higher burden of disease, their lack of access to care, and what can be done about it. While we know that men's burden of disease may be influenced by biological susceptibility, social contact patterns, tobacco smoking, alcohol consumption, undiagnosed or untreated HIV infection, nutrition, and other factors, the relative contribution of these factors is not well-understood. Likewise, while we also know that perceptions of masculinity - specifically pressure to maintain physical strength and to act as a leader and provider - affect men's decisions regarding TB $[45,46]$, the diverse manifestations of masculinity related to TB are not wellunderstood across geographic settings. Even scarcer is evidence to guide efforts to improve men's access to care and retention once in care. Gendered analyses must be incorporated into research on patient pathways and care cascades, particularly with regards to the private sector. It is imperative to identify where men (and women) are delayed and lost to follow-up and how barriers to care can be overcome. Funding agencies should broaden their mandates for gendered research and support social research, mathematical modelling, intervention trials, and economic analyses in each of these areas.

The need for further research should not prohibit immediate action by national TB programmes, non-governmental organisations, and others given current evidence. To date, gender-specific strategies to improve access to TB diagnosis have focused on women, primarily through integration of TB screening with maternal and child health services $[1,16,27,47]$. While these strategies may provide an entry point to care for the entire family and could be expanded to screen men in the household, strategies with tailored interventions and messaging for men are urgently needed. The TB community should draw on lessons from men's engagement in the HIV care cascade [48]. A systematic review of 78 studies in 13 countries found that community-based screening programmes have greater success in reaching men for HIV testing than facility-based strategies [49], with mobile and home testing increasing coverage of men, according to another systematic review of 15 studies in 10 countries [50]. Qualitative research suggests that retention in care can be improved by 
streamlined services or community-based delivery systems, both with messaging that highlights treatment as a means to regain health, restore masculinity, and allow men to continue providing for their families [48]. These strategies should be adapted to reach men for TB diagnosis and treatment. Yet little has been done. To our knowledge, the only programmes specifically working to improve men's access TB diagnosis and treatment are active case finding efforts focused on male-dominated occupational settings in Nigeria [51] and Uganda [52] and a men's primary care clinic that screens all clients for TB in Lesotho [53]. These programmes should be evaluated to determine the most effective and cost-efficient strategies to reach men with TB services, and further efforts should be implemented globally.

The TB community - including policy makers, funding agencies, researchers, programme implementers, advocacy groups, and civil society - has systematically neglected men's needs for decades. This gender blindness towards men reinforces existing gender inequalities and norms and has severe knock-on effects for the health of women, boys, and girls. Without extending the benefits of TB care and prevention to men, the TB community is unlikely to achieve its ambitious targets [3, 24]. All those involved in response to the TB epidemic must shift their understanding of gender away from a limited focus on women's vulnerabilities and towards an evidence-based, gendertransformative response. Men meet the criteria that have been set for key affected populations in TB and should be recognised as such. Now is the time to end the systematic neglect of men in TB.

\section{Acknowledgements}

Authors also acknowledge support from the London School of Hygiene and Tropical Medicine TB Centre and input from Liz Corbett on an earlier draft of this essay. The contents of this document are the sole responsibility of the authors and can under no circumstances be regarded as reflecting the positions of the International Union Against Tuberculosis and Lung Disease (The Union North America) nor those of the Donors.

\section{Funding}


RGW was supported the UK Medical Research Council (MRC) and the UK Department for International Development (DFID) under the MRC/DFID Concordat agreement that is also part of the EDCTP2 programme supported by the European Union (MR/P002404/1), the Bill and Melinda Gates Foundation (TB Modelling and Analysis Consortium: OPP1084276/OPP1135288, SA Modelling for Policy: OPP1110334, CORTIS: OPP1137034, Vaccines: OPP1160830) and UNITAID (4214-LSHTM-Sept15; PO 8477-0-600). RMGJH was supported by the Bill and Melinda Gates Foundation and European Council (Starting Grant, action number 757699) 
Table 1: Current gender-blind language from global policy and funding bodies and recommended evidence-based language. All documents accessed 19 September 2018.

\begin{tabular}{|c|c|c|c|}
\hline Agency & Document & Current text & Recommended text \\
\hline \multirow[t]{3}{*}{$\begin{array}{l}\text { World Health } \\
\text { Organization }\end{array}$} & Tuberculosis and Gender & $\begin{array}{l}\text { "TB can however have particularly severe } \\
\text { consequences for women..." }\end{array}$ & $\begin{array}{l}\text { "TB can have particularly severe consequences } \\
\text { for both genders, and the data show that men } \\
\text { carry a disproportionate burden of disease } \\
\text { incidence and mortality." }\end{array}$ \\
\hline & Tuberculosis and Gender & $\begin{array}{l}\text { "Maternal and child health services present a } \\
\text { strategic entry point for increasing access to TB } \\
\text { services, for both women and their families." }\end{array}$ & $\begin{array}{l}\text { "Maternal and child health services present a } \\
\text { strategic entry point for increasing access to TB } \\
\text { services, for both women and their } \\
\text { families. Additionally, gender-sensitive } \\
\text { programmes are needed to increase access to TB } \\
\text { services among men." }\end{array}$ \\
\hline & Tuberculosis in Women & "Tuberculosis in Women" & "Tuberculosis in Men" \\
\hline \multirow[t]{3}{*}{$\begin{array}{l}\text { StopTB } \\
\text { Partnership }\end{array}$} & $\begin{array}{l}\text { The Global Plan to End TB } \\
2016-2020 \text { (p. 53) }\end{array}$ & $\begin{array}{l}\text { "People who have limited access to quality TB } \\
\text { services [include] women in settings with gender } \\
\text { disparity" }\end{array}$ & $\begin{array}{l}\text { "People who have limited access to quality TB } \\
\text { services [include] men" }\end{array}$ \\
\hline & $\begin{array}{l}\text { Gender Assessment Tool for } \\
\text { National HIV and TB } \\
\text { Responses (p. 8) }\end{array}$ & $\begin{array}{l}\text { "It is essential that the gender assessment considers } \\
\text { the full range of populations and takes a nuanced } \\
\text { approach addressing the needs of key affected } \\
\text { women and girls." }\end{array}$ & $\begin{array}{l}\text { "It is essential that the gender assessment considers } \\
\text { the full range of populations and takes a nuanced } \\
\text { approach addressing the needs of key affected } \\
\text { men, as well as women, girls and boys." }\end{array}$ \\
\hline & $\begin{array}{l}\text { TB REACH Gender Equality } \\
\text { Strategy (p. 2) }\end{array}$ & $\begin{array}{l}\text { "TB REACH investments provide a promising } \\
\text { platform for funding interventions that help } \\
\text { identify bottlenecks and opportunities so as to } \\
\text { ensure that TB health services are more accessible, } \\
\text { affordable and acceptable for females." }\end{array}$ & $\begin{array}{l}\text { "TB REACH investments provide a promising } \\
\text { platform for funding interventions that help } \\
\text { identify bottlenecks and opportunities so as to } \\
\text { ensure that TB health services are more accessible, } \\
\text { affordable and acceptable for men and women." }\end{array}$ \\
\hline \multirow{3}{*}{$\begin{array}{l}\text { Global Fund } \\
\text { to Fight } \\
\text { AIDS, } \\
\text { Tuberculosis } \\
\text { and Malaria }\end{array}$} & $\begin{array}{l}\text { Focus on Women and Girls } \\
\qquad(\text { p. 1) }\end{array}$ & $\begin{array}{l}\text { "Despite great global gains against HIV, } \\
\text { tuberculosis and malaria over the past } 15 \text { years, } \\
\text { women and girls have not made the same } \\
\text { progress as others." }\end{array}$ & $\begin{array}{l}\text { "Despite great global gains against HIV, } \\
\text { tuberculosis and malaria over the past } 15 \text { years, } \\
\text { substantial gender disparities remain." }\end{array}$ \\
\hline & $\begin{array}{l}\text { Focus on Women and Girls } \\
\text { (p. 1) }\end{array}$ & $\begin{array}{l}\text { "In southern and eastern Africa, they [women] are } \\
\text { drastically and disproportionately affected." }\end{array}$ & $\begin{array}{l}\text { "In southern and eastern Africa, women may be } \\
\text { disproportionately affected by HIV, but men are } \\
\text { drastically and disproportionately affected by } \\
\text { TB." }\end{array}$ \\
\hline & $\begin{array}{l}\text { Tuberculosis, Gender and } \\
\text { Human Rights (p. 5) }\end{array}$ & $\begin{array}{l}\text { "Men are generally less likely to have their TB } \\
\text { detected and reported than women ...Women may }\end{array}$ & $\begin{array}{l}\text { "Men are generally less likely to have their TB } \\
\text { detected and reported than women, indicating that }\end{array}$ \\
\hline
\end{tabular}




\begin{tabular}{|c|c|c|c|}
\hline & & $\begin{array}{l}\text { have less access to TB treatment and prevention } \\
\text { services than men." }\end{array}$ & $\begin{array}{l}\text { men may have less access to TB treatment and } \\
\text { prevention services than women." }\end{array}$ \\
\hline & $\begin{array}{l}\text { Tuberculosis, Gender and } \\
\text { Human Rights (p. 8) }\end{array}$ & $\begin{array}{l}\text { "In HIV-endemic areas, TB services and } \\
\text { information should be available to women seeking } \\
\text { HIV care." }\end{array}$ & $\begin{array}{l}\text { "In HIV-endemic areas, TB services and } \\
\text { information should be available to everyone } \\
\text { seeking HIV care." }\end{array}$ \\
\hline & $\begin{array}{c}\text { Gender Equality Strategy } \\
\text { Action Plan 2014-2016 (p. 4) }\end{array}$ & $\begin{array}{l}\text { "Several of [the new funding model's] features can } \\
\text { be leveraged to include and sustain programming } \\
\text { that respond to the needs and rights of women } \\
\text { and girls..." }\end{array}$ & $\begin{array}{l}\text { "Several of [the new funding model's] features } \\
\text { should be leveraged to include and sustain } \\
\text { programming that respond to the needs and rights } \\
\text { of key affected populations..." }\end{array}$ \\
\hline & $\begin{array}{c}\text { Gender Equality Strategy } \\
\text { Action Plan 2014-2016 (p. 9) }\end{array}$ & $\begin{array}{l}\text { "Gender-responsive programming takes into } \\
\text { account women in all their diversity." }\end{array}$ & $\begin{array}{l}\text { "Gender-responsive programming takes into } \\
\text { account men and women in all their diversity." }\end{array}$ \\
\hline & $\begin{array}{l}\text { Key Populations Action Plan } \\
\text { 2017-2022 (p. 6) }\end{array}$ & $\begin{array}{l}\text { "Key Populations in the Tuberculosis Response: } \\
\text { Prisoners and incarcerated populations, people } \\
\text { living with HIV, migrants, refugees and indigenous } \\
\text { populations are all groups that are highly } \\
\text { vulnerable to TB, as well as experiencing } \\
\text { significant marginalization, decreased access to } \\
\text { quality services, and human rights violations." } \\
\end{array}$ & $\begin{array}{l}\text { "Key Populations in the Tuberculosis Response: } \\
\text { Men, prisoners and incarcerated populations, } \\
\text { people living with HIV, migrants, refugees and } \\
\text { indigenous populations are all groups that are } \\
\text { highly vulnerable to TB, as well as experiencing } \\
\text { significant marginalization, decreased access to } \\
\text { quality services, and human rights violations." }\end{array}$ \\
\hline \multirow[t]{4}{*}{$\begin{array}{l}\text { United } \\
\text { Nations } \\
\text { Development } \\
\text { Programme }\end{array}$} & $\begin{array}{l}\text { Gender and Tuberculosis } \\
\text { Discussion Paper (p. 11) }\end{array}$ & $\begin{array}{l}\text { [Recommendations to improve the gender- } \\
\text { sensitivity of programmes] "To maximise the entry } \\
\text { points to TB care for women...Case detection of } \\
\text { TB among women should be improved." }\end{array}$ & $\begin{array}{l}\text { [Recommendations to improve the gender- } \\
\text { sensitivity of programmes] "To maximise the entry } \\
\text { points to TB care for men and women...Case } \\
\text { detection of TB among men should be improved." }\end{array}$ \\
\hline & $\begin{array}{l}\text { Gender and Tuberculosis } \\
\text { Discussion Paper (p. 11) }\end{array}$ & $\begin{array}{l}\text { [Recommendations to strengthen gender-sensitive } \\
\text { monitoring and evaluation] "Countries should } \\
\text { improve TB patient monitoring for women..." }\end{array}$ & $\begin{array}{l}\text { [Recommendations to strengthen gender-sensitive } \\
\text { monitoring and evaluation] "Countries should } \\
\text { improve TB patient monitoring for men..." }\end{array}$ \\
\hline & $\begin{array}{l}\text { Checklist for Integrating } \\
\text { Gender into the Processes and } \\
\text { Mechanisms of the Global } \\
\text { Fund to Fight AIDS, TB and } \\
\text { Malaria (pp. 6, 17) }\end{array}$ & $\begin{array}{l}\text { "Explicit attention has been paid to addressing the } \\
\text { needs and rights of women and girls." }\end{array}$ & $\begin{array}{l}\text { "Explicit attention has been paid to addressing the } \\
\text { needs and rights of men and women, boys and } \\
\text { girls." }\end{array}$ \\
\hline & $\begin{array}{l}\text { Checklist for Integrating } \\
\text { Gender into the Processes and } \\
\text { Mechanisms of the Global } \\
\text { Fund to Fight AIDS, TB and } \\
\text { Malaria (p. 17) }\end{array}$ & $\begin{array}{l}\text { "Adding gender-sensitive elements into basic } \\
\text { programme areas may be an essential 'enabler' to } \\
\text { achieving results, scaling up interventions in a way } \\
\text { that will have positive effects on women and } \\
\text { girls." }\end{array}$ & $\begin{array}{l}\text { "Adding gender-sensitive elements into basic } \\
\text { programme areas may be an essential 'enabler' to } \\
\text { achieving results, scaling up interventions in a way } \\
\text { that will have positive effects on men and women, } \\
\text { boys and girls." }\end{array}$ \\
\hline
\end{tabular}




\section{References}

1. World Health Organization. Tuberculosis and gender. Geneva, Switzerland: World Health Organization; 2017 [19 September 2018]. Available from: http://www.who.int/tb/areas-ofwork/population-groups/gender/en/.

2. The Global Fund to Fight AIDS Tuberculosis and Malaria. Focus on women and girls. Geneva, Switzerland: The Global Fund to Fight AIDS Tuberculosis and Malaria,; 2017 [19 September 2018]. Available from:

https://www.theglobalfund.org/media/1296/publication_womengirls_focuson_en.pdf.

3. Joint United Nations Programme on HIV/AIDS, Stop TB Partnership. Gender assessment tool for national HIV and TB responses. Geneva, Switzerland2016 [19 September 2018]. Available from:

http://www.stoptb.org/assets/documents/resources/publications/acsm/Gender_Assessment_Tool_T B_HIV_UNAIDS_FINAL_2016\%20ENG.pdf.

4. World Health Organization. Case notifications. Geneva, Switzerland: World Health Organization; 2018 [updated 14 June 2018]. Available from:

http://www.who.int/tb/country/data/download/en/.

5. World Health Organization. Global tuberculosis report 2018. Geneva, Switzerland: World Health Organization; 2018 [19 September 2018].

6. Horton KC, Macpherson P, Houben R, White R, Corbett E. Sex differences in tuberculosis burden and notifications in low and middle-income countries: a systematic review and metaanalysis. PLoS Med. 2016;13(9):e1002119. doi: doi: 10.1371/journal.pmed.1002119. 
7. Borgdorff M, Nagelkerke N, Dye C, Nunn P. Gender and tuberculosis: a comparison of prevalence surveys with notification data to explore sex differences in case detection. Int $\mathrm{J}$ Tuberc Lung Dis. 2000;4(2):123-32.

8. Horton KC, Sumner T, Houben RM, Corbett EL, White RG. A Bayesian approach to understanding sex differences in tuberculosis disease burden. American Journal of Epidemiology. 2018.

9. World Health Organization. Global tuberculosis report 2017: Technical appendix. Geneva, Switzerland: World Health Organization, 2017.

10. World Health Organization. WHO TB burden estimates. Geneva, Switzerland: World Health Organization; 2018 [updated 14 June 2018]. Available from:

http://www.who.int/tb/country/data/download/en/.

11. Waitt CJ, Squire SB. A systematic review of risk factors for death in adults during and after tuberculosis treatment. Int J Tuberc Lung Dis. 2011;15(7):871-85. doi: 10.5588/ijtld.10.0352.

12. Velayutham B, Chadha VK, Singla N, Narang P, Rao VG, Nair S, et al. Recurrence of tuberculosis among newly diagnosed sputum positive pulmonary tuberculosis patients treated under the Revised National Tuberculosis Control Programme, India: A multi-centric prospective study. PLoS ONE. 2018;13(7):e0200150.

13. Houben RM, Glynn JR, Mboma S, Mzemba T, Mwaungulu NJ, Mwaungulu L, et al. The impact of HIV and ART on recurrent tuberculosis in a sub-Saharan setting. Aids. 2012;26(17):2233-9.

14. StopTB Partnership. Data for Action for Tuberculosis Key, Vulnerable and Underserved Populations. Geneva, Switzerland: StopTB Partnership; 2017 [19 September 2018]. Available from: 
http://www.stoptb.org/assets/documents/communities/Data\%20for\%20Action\%20for\%20Tubercul osis\%20Key,\%20Vulnerable\%20and\%20Underserved\%20Populations\%20Sept\%202017.pdf.

15. United Nations Development Programme. Gender and Tuberculosis Discussion Paper. United Nations Development Programme: HIV, Health and Development; 2015 [08 February 2018]. Available from: http://www.undp.org/content/dam/undp/library/HIVAIDS/Gender\%20HIV\%20and\%20Health/Gender\%20and\%20TB\%20UNDP\%20Discussion\%20P aper\%20(1).pdf.

16. World Health Organization. Tuberculosis in women. Geneva, Switzerland: World Health Organization; 2016 [19 September 2018]. Available from: http://www.who.int/tb/challenges/hiv/tb_women_factsheet.pdf?ua=1.

17. The Global Fund to Fight AIDS Tuberculosis and Malaria. Gender Equality Strategy. Geneva, Switzerland: The Global Fund to Fight AIDS Tuberculosis and Malaria; [19 September 2018]. Available from:

https://www.theglobalfund.org/media/1250/core_genderequality_strategy_en.pdf.

18. The Global Fund to Fight AIDS Tuberculosis and Malaria. Tuberculosis, Gender and Human Rights. Geneva, Switzerland: The Global Fund to Fight AIDS Tuberculosis and Malaria; 2017 [19 September 2018]. Available from:

https://www.theglobalfund.org/media/6349/core_tbhumanrightsgenderequality_technicalbrief_en.p df.

19. United Nations Development Programme. Checklist for Integrating Gender into the Processes and Mechanisms of the Global Fund to Fight AIDS, TB and Malaria. Geneva, Switzerland: United Nations Development Programme; 2015 [19 September 2018]. Available from: http://www.undp.org/content/undp/en/home/librarypage/hiv-aids/checklist-for-integrating-genderinto-the-new-funding-model-of-t.html. 
20. Stop TB Partnership. A Paradigm Shift 2016-2020: The Global Plan to End TB. Geneva, Switzerland: Stop TB Partnership; 2015 [19 September 2018]. Available from: http://www.stoptb.org/assets/documents/global/plan/GlobalPlanToEndTB_TheParadigmShift_2016 -2020_StopTBPartnership.pdf.

21. StopTB Partnership. TB REACH Gender Equality Strategy. Geneva, Switzerland: StopTB Partnership; 2017 [19 September 2018]. Available from: http://www.stoptb.org/assets/documents/global/awards/tbreach/TBRw6_Gender_Strategy_FINAL.p df.

22. The Global Fund to Fight AIDS Tuberculosis and Malaria. Gender Equality Strategy Action Plan 2014-2016. Geneva, Switzerland: The Global Fund to Fight AIDS Tuberculosis and Malaria; 2014 [19 September 2018]. Available from:

https://www.theglobalfund.org/media/1247/publication_genderequalitystrategy_actionplan_en.pdf.

23. United Nations General Assembly. United Nations Millenium Declaration. 200018 September 2000. Document No.: A/55/L.2.

24. United Nations General Assembly. Transforming our world: the 2030 Agenda for Sustainable Development. 2015 [updated 18 September 201508 February 2018]. Available from: http://www.un.org/ga/search/view_doc.asp?symbol=A/RES/70/1\&Lang=E.

25. Bates M, Ahmed Y, Kapata N, Maeurer M, Mwaba P, Zumla A. Perspectives on tuberculosis in pregnancy. International Journal of Infectious Diseases. 2015;32:124-7.

26. Thorson A. Gender issues in tuberculosis. In: Klein S, Roberts C, editors. Sex and Gender Differences in Infection and Treatments for Infectious Diseases. Switzerland: Springer International Publishing; 2015. 
27. United Nations Development Programme. Gender and Tuberculosis Discussion Paper. United Nations Development Programme: HIV, Health and Development; 2015 [19 September 2018]. Available from: http://www.undp.org/content/dam/undp/library/HIV-

AIDS/Gender\%20HIV\%20and\%20Health/Gender\%20and\%20TB\%20UNDP\%20Discussion\%20P aper\%20(1).pdf.

28. The Global Fund to Fight AIDS Tuberculosis and Malaria. The Global Fund Strategy 20172022: Investing to End Epidemics. Abidjan, Côte d'Ivoire: The Global Fund to Fight AIDS Tuberculosis and Malaria; 2016 [19 September 2018]. Available from: https://www.theglobalfund.org/media/1176/bm35_02-theglobalfundstrategy20172022investingtoendepidemics_report_en.pdf.

29. KNCV Tuberculosis Foundation. TB Stigma Measurement Guidance. The Hague, The Netherlands: KNCV Tuberculosis Foundation; 2018 [19 September 2018]. Available from: https://www.challengetb.org/publications/tools/ua/TB_Stigma_Measurement_Guidance.pdf.

30. AIDSinfo: HIV prevalence [Internet]. Joint United Nations Programme on HIV/AIDS. 2016 [cited 08 August 2017]. Available from: http://aidsinfo.unaids.org/.

31. Kulchavenya E. Extrapulmonary tuberculosis: are statistical reports accurate? Therapeutic advances in infectious disease. 2014;2(2):61-70.

32. MEASURE Evaluation. The importance of gender in tuberculosis data. Chapel Hill, NC: MEASURE Evaluation; 2017 [19 September 2018]. Available from: https://www.measureevaluation.org/resources/publications/fs-17-205f/at_download/document.

33. World Health Organization. Global Health Estimates 2015: Deaths by Cause, Age, Sex, by Country and by Region, 2000-2015. Geneva, Switzerland: World Health Organization; 2016 [12 April 2018]. Available from:

http://www.who.int/gho/mortality_burden_disease/causes_death/top_10/en/. 
34. Allotey P, Gyapong M. Gender in tuberculosis research. International Journal of Tuberculosis and Lung Disease. 2008;12(7):831-6.

35. Krishnan L, Akande T, Shankar AV, McIntire KN, Gounder CR, Gupta A, et al. Genderrelated barriers and delays in accessing tuberculosis diagnostic and treatment services: a systematic review of qualitative studies. Tuberculosis Research and Treatment. 2014;2014.

36. Yang W-T, Gounder CR, Akande T, De Neve J-W, McIntire KN, Chandrasekhar A, et al. Barriers and delays in tuberculosis diagnosis and treatment services: does gender matter? Tuberculosis Research and Treatment. 2014;2014.

37. Perumal R, Naidoo K, Padayatchi N. TB epidemiology: where are the young women? Know your tuberculosis epidemic, know your response. BMC public health. 2018;18(1):417.

38. Boyce C. Are women and girls more vulnerable to tuberculosis and malaria? Geneva, Switzerland: United Nations Development Programme; 2016 [08 February 2018]. Available from: http://www.undp.org/content/undp/en/home/blog/2016/3/23/Are-women-and-girls-morevulnerable-to-tuberculosis-and-malaria.html.

39. The Global Fund to Fight AIDS Tuberculosis and Malaria. Key populations action plan 2017-2022. Geneva, Switzerland: The Global Fund to Fight AIDS Tuberculosis and Malaria; 2017 [19 September 2018]. Available from: https://www.theglobalfund.org/media/1270/publication_keypopulations_actionplan_en.pdf.

40. Global Fund Advocates Network \& Free Space Process Partnership. Key Populations and the Global Fund: Delivering Key Results. 2016 [19 September 2018]. Available from: http://www.globalfundadvocatesnetwork.org/wp-content/uploads/2016/07/GFAN-Key-Populationsthe-Global-Fund-full-report-JUN2016.pdf. 
41. Lönnroth K, Jaramillo E, Williams BG, Dye C, Raviglione M. Drivers of tuberculosis epidemics: the role of risk factors and social determinants. Social science \& medicine. 2009;68(12):2240-6.

42. United Nations Department of Economic and Social Affairs Population Division. File POP/8-2: Male population by broad age group, major area, region and country, 1950-2100 (thousands). 2017 [19 September 2018]. Available from: https://esa.un.org/unpd/wpp/DVD/Files/1_Indicators\%20(Standard)/EXCEL_FILES/1_Population/ WPP2017_POP_F08_2_TOTAL_POPULATION_BY_BROAD_AGE_GROUP_MALE.xlsx.

43. United Nations Department of Economic and Social Affairs Population Division. File POP/8-3: Female population by broad age group, major area, region and country, 1950-2100 (thousands). 2017 [19 September 2018]. Available from: https://esa.un.org/unpd/wpp/DVD/Files/1_Indicators\%20(Standard)/EXCEL_FILES/1_Population/ WPP2017_POP_F08_3_TOTAL_POPULATION_BY_BROAD_AGE_GROUP_FEMALE.xlsx.

44. Dodd PJ, Looker C, Plumb I, Bond V, Schaap A, Shanaube K, et al. Age- and sex-specific social contact patterns and incidence of Mycobacterium tuberculosis infection. American Journal of Epidemiology. 2016;183(2):156-66. doi: 10.1093/aje/kwv160.

45. Chikovore J, Hart G, Kumwenda M, Chipungu GA, Desmond N, Corbett L. Control, struggle, and emergent masculinities: a qualitative study of men's care-seeking determinants for chronic cough and tuberculosis symptoms in Blantyre, Malawi. BMC public health. 2014;14:1053. doi: doi: 10.1186/1471-2458-14-1053.

46. Johansson E, Long N, Diwan V, Winkvist A. Gender and tuberculosis control: perspectives on health seeking behaviour among men and women in Vietnam. Health Policy. 2000;52(1):33-51.

47. United States Agency for International Development. United States Government Global Tuberculosis Strategy 2015-2019. Washington, DC: United States Government; [08 February 
2018]. Available from: https://www.usaid.gov/sites/default/files/documents/1864/Reach-CurePrevent-2015-2019-TBStrategy.pdf.

48. Sharma M, Barnabas R, Celum C. Community-based strategies to strengthen men's engagement in the HIV care cascade in sub-Saharan Africa. PLoS medicine. 2017;14(4):e1002262.

49. Sharma M, Ying R, Tarr G, Barnabas R. Systematic review and meta-analysis of community and facility-based HIV testing to address linkage to care gaps in sub-Saharan Africa. Nature. 2015;528:S77. doi: 10.1038/nature16044

https://www.nature.com/articles/nature16044\#supplementary-information.

50. Hensen B, Taoka S, Lewis JJ, Weiss HA, Hargreaves J. Systematic review of strategies to increase men's HIV-testing in sub-Saharan Africa. Aids. 2014;28(14):2133-45.

51. Chukwueme N, Gidado M, Mitchell E, Abdur-Razzaq H, Adegbola A, Ogbudebe C, et al. Strategies for reaching men through occupational screening in Lagos, Nigeria. Union World Conference on Lung Health; Liverpool, United Kingdom2016.

52. USAID Applying Science to Strengthen and Improve Systems (ASSIST) Project. A guide to increasing TB screening amongst the fishing communities: USAID ASSIST Experience from Northern Uganda. Chevy Chase, MD: USAID Applying Science to Strengthen and Improve Systems (ASSIST) Project; 2017 [19 September 2018]. Available from:

https://www.usaidassist.org/sites/default/files/guide_to_tb_screening_among_fishing_community_ march_2017.pdf.

53. Ramapepe M, Rozario A, Stender S, Matsinyane P. Assessing sensitivity of symptoms for efficiency in TB case detection in a male clinic in Lesotho. In: Disease IUATaL, editor. Union World Conference on Lung Health; Guadalajara, Mexico2017. 